\title{
Pengaruh Pemberian Lumpur Minyak Sawit yang Difermentasi dengan Kapang Trichoderma Harzianum terhadap Pertambahan Bobot Badan dan Efisiensi Pakan Babi Bali
}

\author{
Effect of Palm Oil Sludge Fermented by using Trichoderma Harzianum molds \\ on Body Weight Gain and Feed Efficiency of Bali Pigs \\ Siwitri Kadarsih, Bieng Brata dan Roslin Lumbantoruan \\ Jurusan Peternakan Fakultas Pertanian Universitas Bengkulu \\ Jalan Raya Kandang Limun, Bengkulu. Telp. (0736) 2170 pst.219.
}

\begin{abstract}
The research was aimed to evaluate effect of palm oil sludge fermented by using Trichoderma Harzianum molds on Body Weight Gain and Feed Efficiency of Bali Pigs. The experiment was set up in a completely randomized design with five levels of treatment and three replications. The treatment levels were R0 (without palm oil sludge), R1 ( $5 \%$ fermented palm oil sludge), R2 (10\% fermented palm oil sludge), R3 ( $15 \%$ fermented palm oil sludge), R4 (20\% fermented palm oil sludge). Results of the research showed supplementation of $15 \%$ fermented palm oil oil sludge significantly affected on body weight gain and feed consumption, as well as feed convertion $(\mathrm{P}<0.01)$.
\end{abstract}

Key words : palm oil sludge, Trichoderma harzianum, body weight gain, feed efficiency, Bali pig.

\begin{abstract}
ABSTRAK
Penelitian bertujuan untuk mengevaluasi pengaruh pemberian lumpur minyak sawit yang difermentasi dengan kapang Trichoderma harzianum terhadap pertambahan bobot badan dan efisiensi pakan babi bali. Penelitian ini menggunakan Rancangan Acak Lengkap dengan 5 perlakuan dan 3 ulangan. R0 (tanpa pemberian lumpur sawit), R1 (pemberian 5\% lumpur sawit fermentasi), R2 (pemberian 10\% lumpur sawit fermentasi), R3 (pemberian 15\% lumpur sawit fermentasi), R4 (pemberian 20\% lumpur sawit fermnetasi). Variabel yang diamati meliputi pertambahan bobot badan, konsumsi pakan dan konversi pakan. Hasil penelitian menunjukkan bahwa lumpur sawit fermentasi sangat berpengaruh nyata terhadap pertambahan bobot badan dan konsumsi pakan pada pemberian $15 \%$ lumpur sawit fermentasi, dan berpengaruh nyata terhadap konversi pakan pada pemberian $15 \%$ lumpur sawit fermentasi.
\end{abstract}

Kata Kunci : Lumpur minyak Sawit, Trichoderma harzianum, pertambahan bobot badan, efisiensi pakan, babi Bali.

\section{PENDAHULUAN}

Beternak babi merupakan salah satu usaha yang memiliki potensi besar untuk dikembangkan karena laju pertumbuhan yang cepat, litter size yang tinggi dan permintaan daging yang cukup tinggi. Anonimus (1999) menyebutkan bahwa permintaan akan daging babi di Indonesia sekitar satu juta kg per tahun. Dengan demikian maka tujuan beternak babi yaitu untuk menghasilkan karkas yang banyak mengandung daging dengan hasil buangan yang sedikit mungkin.Sihombing (1997) menyatakan bahwa peternakan di negara maju mempunyai tujuan untuk menghasilkan daging yang berkualitas baik atau tinggi. Selain itu menurut Reksohadiprodjo (1984), bahwa peternakan babi di seluruh dunia untuk memanfaatkan daging dan hasil sampingnya kulit serta pupuk. Babi memerlukan pakan yang merupakan salah satu faktor yang sangat berpengaruh dalam peternakan. Biaya 
pakan dapat mencapai $60-70 \%$ dari total biaya produksi secara keseluruhan (Anggorodi, 1995). Untuk itu penyediaan pakan yang berkualitas sangat perlu dilakukan dengan biaya yang relatif murah.

Lumpur minyak sawit merupakan suatu produk sampingan atau limbah pengolahan minyak kelapa sawit. Produksi lumpur minyak sawit akan terus menigkat dengan meningkatnya produksi minyak sawit. Pada tahun 2000, produksi minyak sawit adalah sebesar 5,8 juta ton (BPS, 2000). Pada proses produksi CPO dihasilkan lumpur minyak sawit sebanyak $2 \%$ dari minyak sawit. Lumpur minyak sawit yang dihasilkan industri pengolahan minyak sawit belum dimanfaatkan secara ekonomi. Di areal perkebunan, lumpur sawit digunakan sebagai penimbun jurang, bahkan lumpur sawit sering dibuang sembarang sehingga menimbulkan polusi bagi mayarakat di sekitar perkebunan (Yeon, 1982; Medan Pos; 1998).

Perez (1997), mengemukakan bahwa lumpur minyak sawit segar dapat diberikan dalam ransum ternak babi hingga 14\%. Selanjutmya bahwa lumpur sawit kering dapat diberikan hingga 20\% kepada ternak babi periode pertumbuhan penggemukan. Farrel (1986) menyarankan pemberian lumpur minyak sawit dalam ransum ternak babi hanya $15 \%$. Perkebunan kelapa sawit di Indonesia yang setiap tahun meningkat sejalan dengan pertambahan penduduk yang menghasilkan minyak dan limbah minyak sawit yang dapat meningkatkan keuntungan (Devendra, 1997). Di Bengkulu juga, jumlah perkebunan kelapa sawit terus meningkat dari tahun ke tahun (Lubis, 1995). Beberapa keuntungan dan pemanfaatan hasil perkebunan ini adalah secara teknis mudah didapat, produksi berkesinambungan, dan secara ekonomis membantu meningkatkan pendapatan perkebunan, membantu pengawasan lingkungan, mengurangi pencemaran dan menambah penyediaan bahan baku. Di lain pihak, bau yang menyengat pada lumpur minyak sawit akan mengurangi konsumsi dan palatabilitas ternak babi. Untuk mengatasi hal tersebut, perlu dilakukan proses fermentasi lumpur sawit yaitu dengan menggunakan kapang Trichoderma harzianum sebagai campuran pakan. Manalu (1998) mengemukakan bahwa lumpur minyak sawit yang telah difermentasi dengan kapang Trichoderma harzianum dapat digunakan sebagai campuran pakan ayam broiler. Lumpur sawit mengandung serat kasar yang tinggi serta daya cerna yang rendah (Abas, 1984). Menurut Reese et al,. (1950) di sitasi Brata (1997) kapang selulotik mempunyai enzim $\mathrm{Cl}$ dan $\mathrm{CX}$ yang bekerja secara sinergis dalam memecahkan substrat komplek. Pengolahan secara biologis terhadap limbah yang mengandung lignosellulosa salah satunya kapang (Brata, 1997).

Lumpur sawit perlu diteliti terutama untuk memaksimalkan peningkatan produktivitas dan sekaligus meningkatkan komposisi nutrisi babi bali. Dengan demikian perlu dilakukan penelitian yang berurutan, yang nantinya akan diperoleh hasil akhir suatu formula tepat dari lumpur minyak sawit yang telah difermentasi sebagai suplemen pakan alternatif yang dapat meningkatkan produktifitas dan sekaligus memperbaiki kualitas nutrisi babi bali. Penggunaan lumpur sawit fermentasi yang difermentasi dengan kapang Trichoderma harzianum dapat digunakan sebagai pakan alternatif untuk meningkatkan produktifitas dan perbaikan nutrisi babi Bali. Berdasarkan uraian di atas maka mendorong minat penulis untuk melakukan penelitian tentang pemanfaatan lumpur minyak sawit fermentasi terhadap pertambahan bobot badan dan efesiensi pakan babi bali.

Penelitian ini bertujuan untuk mengevaluasi pengaruh pemberian 
lumpur minyak sawit yang difermentasi dengan kapang Trichoderma harzianum terhadap pertambahan bobot badan dan efisiensi pakan babi bali. Hipotesis penelitian ini adalah Penggunaan lumpur minyak sawit yang difermentasi dengan kapang Trichoderma harzianum dapat meningkatkan pertambahan bobot badan dan meningkatkan efisiensi pakan babi bali.

\section{MATERI DAN METODE}

Penelitian ini dilaksanakan di desa Rama Agung Kecamatan Arga Makmur Kabupaten Bengkulu Utara dari tanggal 1 Juli sampai dengan 1 September 2006.

Bahan yang digunakan dalam penelitian terdiri dari 15 ekor babi bali, Lumpur Minyak Sawit yang difermentasi dengan kapang Trichoderma harzianum, jagung, dedak padi, tepung ikan, ampas tahu. Alat yang digunakan adalah tempat pakan dan minum yang terbuat dari kayu, kandang 15 unit, timbangan, drum, ember, thermometer, hygrometer, dan kamera.

\section{Persiapan Kandang Pemeliharaan}

Sebelum penelitian dimulai, terlebih dahulu membuat kandang sebanyak 15 unit dengan masing-masing ukuran $1 \mathrm{~m} \times 0,75 \mathrm{~m}$ yang terbuat dari kayu. Menyediakan tempat pakan yang terbuat dari kayu. Kandang babi disucihamakan terlebih dahulu dengan menggunakan desinfektan.

\section{Penentuan Ternak}

Penelitian ini menggunakan ternak 15 ekor babi bali lepas sapih umur 8 minggu. Pemilihan umur sangat penting karena mengingat ternak pada umur lepas sapih adalah umur produktiv pada ternak.

\section{Persiapan Lumpur Sawit}

Lumpur sawit diambil dari PT. Bio Nusantara Pondok Kelapa, setelah itu lumpur sawit dikeringanginkan selama tiga hari. Sementara itu galur Trichoderma harzianum ditumbuhkan pada medium PDA sampai berumur tiga hari. Dedak dipersiapkan sebanyak 200 gram dan ditambah air sehingga kadar airnya kirakira $65 \%$. Setelah itu dimasukan ke dalam kantong plastik dan disterilkan dengan autoklaf selama 2 jam $\left(120^{\circ} \mathrm{C}\right.$; 1 Atm) lalu dinokulasi selama 3 hari. Medium ini siap digunakan sebagai inokulum percobaan fermentasi. Sebanyak $7 \%$ inokulum Trichoderma harzianum dan lumpur sawit per 200 gram bahan fermentasi dan diperkaya dengan urea dan sumber mineral yakni: urea 5 gram, $\mathrm{MGSO}_{4} 7 \mathrm{H}_{2} \mathrm{O}$ 0,25 gram, $\mathrm{FeS}_{4} \mathrm{O} \quad 7 \mathrm{H}_{2} \mathrm{O} \quad 0,10 \mathrm{mg}, \mathrm{ZnSO}_{4}$ $7 \mathrm{H}_{2} \mathrm{O} \quad 0,10 \mathrm{mg}, \mathrm{MnSO}_{4} \quad 4 \mathrm{H}_{2} \mathrm{O} \quad 0,10 \mathrm{mg}$, $\mathrm{MnSO}_{4} 4 \mathrm{H}_{2} \mathrm{O} \quad 0,10 \mathrm{mg}, \mathrm{KH}_{2} \mathrm{PO}_{4} 1$ gr dan thiamin hidrochorit $12,50 \mathrm{mg}$. sebanyak 12 $\mathrm{ml}$ campuran urea dan mineral digunakan untuk sumber nutrient dan difermentasi selama 8 hari. Setelah lumpur sawit difermentasikan, maka siap digunakan sebagai campuran tambahan pakan babi bali.

\section{Pemeliharaan Babi Bali}

Pakan lumpur sawit fermentasi diberikan selama 8 minggu. Babi bali ditempatkan pada kandang, setiap kandang terdiri dari satu ekor babi. Setiap perlakuan terdiri dari 3 ekor babi sebagai ulangan.

\section{Pemberian pakan}

Adapun cara pemberian dilakukan pada pagi hari dan sore hari sesuai dengan perlakuan pemberian $0 \%, 5 \%, 10 \%, 15 \%$, dan 20\% lumpur sawit fermentasi dicampur dengan pakan tepung jagung, dedak padi, tepung ikan, dan ampas tahu. Selama penelitian berlangsung dilakukan pengukuran suhu dan kelembaban pada 
pukul 7.00 WIB, pukul $12.00 \mathrm{WIB}$, dan pukul 17.00 WIB.

\section{Pengamatan}

Penimbangan berat badan babi dilakukan setiap minggu untuk mengetahui pertambahan berat badan babi bali, penimbangan sisa pakan diadakan setiap hari untuk mengetahui jumlah pakan yang dikonsumsi.

\section{Metode Penelitian}

Penelitian ini menggunakan Rancangan Acak Lengkap (RAL) menggunakan lima perlakuan, tiap perlakuan dengan tiga kali ulangan. Secara rinci dapat dilihat di bawah ini:

R0 : Ransum tanpa pemberian lumpur sawit

R1 : Ransum dengan pemberian lumpur minyak sawit fermentasi $5 \%$

R2 : Ransum dengan pemberian lumpur minyak sawit fermentasi $10 \%$

R3 : Ransum dengan pemberian lumpur minyak sawit fermentasi $15 \%$

R4 : Ransum dengan pemberian lumpur minyak sawit fermentasi $20 \%$

Data yang diperoleh dari hasil penelitian tersebut diuji secara statistik dan apabila sidik ragam menunjukkan perbedaan yang nyata, maka analisis akan dilanjutkan dengan uji beda rataan Duncan's Multiple Range Test.
Variabel yang diamati

Pertambahan Berat Badan (g/ekor/minggu)

Pengukuran pertambahan berat badan didasarkan pada rata-rata bobot badan akhir dikurangi rata-rata bobot badan awal selama delapan minggu.

\section{Konsumsi Pakan (g/ekor/minggu)}

Perhitungan pakan didasarkan dengan mengurangi jumlah pakan yang diberikan dengan jumlah pakan yang sisa selama delapan minggu.

\section{Konversi pakan}

Konversi ransum adalah perbandingan antara konsumsi ransum dengan pertambahan berat badan (Fati, 1997).

konversipdan: $\frac{\text { konsumsiransum }}{\text { pertambahaberatbada }} X 100 \%$

\section{Variabel pendukung}

Variabel pendukung yang diamati adalah kelembaban, dan temperatur. Kelembaban dan temperatur diukur pada pukul 07.00 WIB, pukul $12.00 \mathrm{WIB}$, dan pukul 17.00 WIB. Kelembaban diukur dengan menggunakan hygrometer, sedangkan temperatur diukur dengan menggunakan thermometer.

Tabel 1. Susunan bahan ransum perlakuan

\begin{tabular}{llllll}
\hline Bahan makanan (\%) & R0 & R1 & R2 & R3 & R4 \\
\hline Jagung & 29.00 & 27.00 & 24.00 & 23.00 & 22.00 \\
Lumpur minyak sawit fermentasi & 00.00 & 5.00 & 10.00 & 15.00 & 20.00 \\
Dedak padi & 40.00 & 36.00 & 32.50 & 28.00 & 23.00 \\
Tepung ikan & 10.00 & 10.00 & 10.00 & 10.00 & 10.00 \\
Ampas tahu & 21.00 & 22.00 & 23.50 & 24.00 & 25.00 \\
\hline Total & 100 & 100 & 100 & 100 & 100 \\
\hline Protein kasar $(\%)$ & 16.36 & 16.61 & 16.79 & 16.90 & 16.90 \\
Energi (Kkal/kg) & 2290.3 & 2392.25 & 2477.65 & 2596.15 & 2715.5 \\
\hline
\end{tabular}

Pengaruh Pemberian Lumpur Minyak Sawit 
ISSN $1978-3000$

Tabel 2. Daftar susunan zat-zat makanan yang digunakan dalam penelitian

\begin{tabular}{|c|c|c|c|c|c|c|c|}
\hline Bahan makanan (\%) & & BK & PK & Lemak & SK & Energi & $\mathrm{Abu}$ \\
\hline Jagung & & 87.08 & 7.68 & 2.72 & 3.78 & 3370 & 1.16 \\
\hline Lumpur & Sawit & $89.81^{*}$ & $13.62^{* *}$ & $37.91^{*}$ & $15.34^{*}$ & $4331^{* *}$ & $23.4^{*}$ \\
\hline \multicolumn{8}{|l|}{ Fermentasi (LMS) } \\
\hline Dedak padi & & 85.65 & 12.99 & 9.00 & 13.83 & 1630 & 10.88 \\
\hline Tepung ikan & & 89.80 & 37.82 & 6.52 & 1.78 & 2830 & 35.01 \\
\hline Ampas tahu & & 97.10 & 24.56 & 10.13 & 23.58 & 1800 & 3.51 \\
\hline
\end{tabular}

Sumber : Anonimus 1981.

Ket : * Analisa Lab. Peternakan Fakultas Pertanian UNIB )1998) dalam Erwin (1998)

** Analisa Lab. Ilmu Tanah Fakultas Pertanian UNIB )1998) dalam Erwin (1998

Tabel 3. Hasil analisis lumpur minyak sawit fermentasi

\begin{tabular}{cccccc}
\hline \multirow{2}{*}{ Komponen } & \multicolumn{5}{c}{ R0 } \\
\cline { 2 - 6 } & $\begin{array}{l}\text { (tanpa } \\
\text { fermentasi) }\end{array}$ & R1 (5\% LSF) & R2 (10\% LSF) & R3 (15\% LSF) & R4 (LSF) \\
\hline Protein (\%) & 10,76 & 11,28 & 11,70 & 12,29 & 12,59 \\
\hline
\end{tabular}

Keterangan : Hasil analisis laboratorium Teknologi Pertanian Fakultas Pertanian Universitas Bengkulu, 2006

Susunan ransum perlakuan dan nilai nutrisi perlakuan serta hasil analisis lumpur minyak sawit tertera pada tabel 1 3 di atas.

\section{HASIL DAN PEMBAHASAN}

\section{Pertambahan Bobot Badan Babi Bali}

Rataan pertambahan bobot badan babi bali dari setiap perlakuan selama penelitian ditampilkan pada tabel 4 .

Berdasarkan Tabel 4, didapat rataan pertambahan bobot badan babi bali pada perlakuan tanpa pemberian lumpur minyak sawit fermentasi sebesar 2057,42 g/ekor/minggu, pemberian 5\% lumpur minyak sawit fermentasi 2485,00 g/ekor/minggu, pemberian $10 \%$ lumpur minyak sawit fermentasi 2784,83g/ekor/minggu, pemberian 15\% lumpur minyak sawit 3721,67 g/ekor/minggu, dan pemberian $20 \%$ lumpur minyak sawit fermentasi rataan pertambahan bobot badan babi bali sebesar 2272,38 g/ekor/minggu.

Hasil analisis sidik ragam menunjukkan bahwa pemberian lumpur minyak sawit yang difermentasikan dengan kapang Trichoderma harzianum berpengaruh sangat nyata $(\mathrm{P}<0,01)$ terhadap pertambahan berat badan babi bali. Terdapatnya perbedaan pertambahan berat badan babi bali disebabkan oleh adanya perbedaan pemberian lumpur minyak sawit yang difermentasi dengan kapang Trichoderma harzianum. Trichoderma harzianum memiliki enzim CL dan CX yang merombak selulase yang bekerja secara sinergik (Wiseman, 1981 dalam Brata, 1997). 
ISSN $1978-3000$

Tabel 4. Rataan pertambahan berat badan babi bali

\begin{tabular}{|c|c|c|c|c|c|}
\hline \multirow{2}{*}{ Perlakuan } & \multicolumn{3}{|c|}{ Pertambahan berat badan (g/ekor/minggu) } & \multirow{2}{*}{ Jumlah } & \multirow{2}{*}{ Rataan } \\
\hline & 1 & 2 & 3 & & \\
\hline R0 & 1967.00 & 2059.75 & 2145.50 & 6172.25 & $2057.42^{\mathrm{d}}$ \\
\hline R1 & 2397.50 & 2435.13 & 2622.38 & 7455.00 & $2485.00^{\mathrm{bc}}$ \\
\hline $\mathrm{R} 2$ & 2735.25 & 2747.50 & 2871.75 & 8354.50 & $2784.83^{\mathrm{b}}$ \\
\hline $\mathrm{R} 3$ & 3560.38 & 3983.00 & 3621.63 & 11165.00 & $3721.67^{a}$ \\
\hline $\mathrm{R} 4$ & 2285.50 & 2222.50 & 23.9 .13 & 6817.13 & $2272.38^{\mathrm{cd}}$ \\
\hline
\end{tabular}

Keterangan : R0: Tanpa pemberian lumpur minyak sawit fermentasi, R1: lumpur mnyak sawit fermentasi 5\%, R2 : pemberian lumpur minyak sawit fermentasi 10\%, R3 : pemberian lumpur minyak sawit fermentasi 15\%, R4: pemberian lumpur minyak sawit fermentasi $20 \%$. Superskrip yang berbeda pada kolom rataan menunjukkan berbeda sangat nyata $(\mathrm{P}<0,01)$

Hasil uji lanjut DMRT menunjukkan bahwa pertambahan berat badan babi bali pada pemberian $15 \%$ lumpur sawit fermentasi berbeda sangat nyata $(\mathrm{P}<0,01)$ dengan pemberian $5 \%, 10 \%$, $20 \%$ dan dibandingkan dengan tanpa pemberian lumpur sawit fermentasi.

Rendahnya pertambahan berat badan babi bali tanpa pemberian lumpur minyak sawit fermentasi disebabkan oleh tidak adanya pemberian lumpur minyak sawit fermentasi yang menyebabkan kecilnya palatabilitas ternak yang dilihat dari penurunan konsumsi pakan.

Tingginya rata-rata pertambahan berat badan babi bali pemberian $15 \%$ lumpur minyak sawit fermentasi disebabkan oleh tingkat pemberian lumpur minyak sawit fermentasi pada taraf $15 \%$ yang mempengaruhi palatabilitas ternak pada perlakuan $15 \%$ yang lebih tinggi dari pada pemberian $5 \%$, dan $10 \%$ dan tanpa pemberian lumpur minyak sawit fermentasi.

Tingginya rata-rata pertambahan berat badan babi bali juga disebabkan oleh lumpur sawit yang difermentasi dengan kapang Tricoderma harzianum lebih kaya dengan vitamin B1 yang berasal dari sumbangan Tricoderma harzianum sewaktu proses fermentasi, dimana vitamin B1 dapat merangsang nafsu makan pada ternak. Sesuai dengan pendapat Anggorodi
(1997) yang menyatakan bahwa dari semua zat makanan, vitamin B1 mempunyai pengaruh paling banyak terhadap nafsu makan. Tingginya rata-rata pertambahan berat badan babi bali pada pemberian $15 \%$ lumpur minyak sawit fermentasi juga disebabkan oleh konsumsi pakan yang lebih tinggi yang disebabkan oleh aroma yang segar dari lumpur minyak sawit fermentasi sebagaimana dikemukakan oleh Brata (1997), hasil fermentasi dapat meningkatkan palatabilitas ransum, sehingga konsumsi ransum dapat meningkat.

Pada taraf pemberian 15\% lumpur minyak sawit fermentasi, babi mampu mansintesa kandungan gizi lumpur sawit. Sinurat et al., (2000) menyatakan bahwa pada batas penberian $15 \%$ lumpur minyak sawit fermentasi tidak mengganggu pertumbuhan, konsumsi ransum dan persentase karkas. Pada batas 15\% pemberian lumpur minyak sawit fermentasi, babi masih mampu mentolerir kandungan pakan lumpur sawit.

Pada taraf pemberian 20\% lumpur minyak sawit fermentasi, pertambahan bobot badan babi bali lebih kecil dibanding pemberian $15 \%$, hal ini disebabkan karena diduga pemberian $20 \%$ lumpur minyak sawit fermentasi tidak dapat ditolerir oleh babi bali. Sinurat (2000) menyatakan semakin tinggi pemberian lumpur minyak 
Tabel 5. Rataan konsumsi pakan babi bali

\begin{tabular}{cccccc}
\hline \multirow{2}{*}{ Perlakuan } & \multicolumn{2}{c}{ Konsumsi pakan $(\mathrm{g} / \mathrm{ek}$ / $/ \mathrm{minggu})$} & \multirow{2}{*}{ Jumlah } & \\
\cline { 2 - 4 } & 1 & 2 & 3 & & $15581.04^{\mathrm{b}}$ \\
R0 & 14800.69 & 15285.88 & 16656.56 & 46743.13 & $17704.58^{\mathrm{b}}$ \\
R1 & 16520.06 & 18939.25 & 17654.44 & 53113.75 & $19315.48^{\mathrm{ab}}$ \\
R2 & 18889.63 & 19302.75 & 19754.06 & 57946.44 & $23442.83^{\mathrm{a}}$ \\
R3 & 23204.06 & 24611.63 & 22512.81 & 70328.50 & $16896.31^{\mathrm{b}}$ \\
R4 & 17127.00 & 16422.00 & 17139.4 & 50688.94 & 164
\end{tabular}

Keterangan: R0:Tanpa pemberian Lumpur sawit fermentasi, R1: Lumpur sawit fermentasi 5\%, R2:Lumpur sawit fermentasi 10\%, R3: Lumpur sawit fermentasi 15\%, R4: Lumpur sawit fermentasi $20 \%$. Superskrip yang berbeda pada kolom rataan menunjukkan berbeda sangat nyata $(\mathrm{P}<0,01)$

sawit akan menyebabkan penurunan performans, konsumsi ransum dan pertumbuhan yang lebih lambat. Selanjutnya Karo-karo et al., (1994) menyatakan bahwa taraf pemberian lumpur sawit fermentasi pada babi yaitu sampai batas $15 \%$.

\section{Konsumsi Pakan}

Rataan konsumsi pakan babi bali dari setiap perlakuan selama penelitian ditampilkan pada tabel 5 di atas.

Berdasarkan Tabel 5, didapat rataan komsumsi pakan babi bali pada perlakuan tanpa pemberian lumpur sawit fermentasi sebesar $\quad 15581.04 \quad \mathrm{~g} / \mathrm{ekor} / \mathrm{minggu}$, pemberian $5 \%$ lumpur sawit fermentasi sebesar $17704.58 \mathrm{~g}$ /ekor/minggu, pemberian $10 \%$ lumpur sawit fermentasi sebesar $\quad 18219.05 \quad$ g/ekor/minggu, pemberian $15 \%$ lumpur sawit fermentasi sebesar 70328.44 g/ekor/minggu, dan pemberian $20 \%$ lumpur sawit fermentasi sebesar $16896.29 \mathrm{~g} / \mathrm{ekor} / \mathrm{minggu}$.

Hasil analisis sidik ragam menunjukkan bahwa pemberian lumpur minyak sawit fermentasi yang difermentasi dengan kapang Trichoderma harzianum berpengaruh sangat nyata $(\mathrm{P}<0,01)$ terhadap konsumsi pakan babi bali. Perbedaan konsumsi pakan babi bali disebabkan oleh adanya perbedaan pemberian Lumpur minyak sawit yang difermentasi dengan kapang Trichoderma harzianum.

Hasil uji lanjut DMRT menunjukkan bahwa konsumsi pakan babi bali pada pemberian $15 \%$ menunjukkan pengaruh yang berbeda nyata $(\mathrm{P}<0,01)$ dengan pemberian $5 \%, 20 \%$ dan dibandingkan tanpa pemberian lumpur minyak sawit fermentasi namun tidak berbeda nyata dengan pemberian $10 \%$ lumpur sawit fermentasi.

Rendahnya konsumsi pakan babi bali tanpa pemberian lumpur minyak sawit fermentasi disebabkan oleh tidak adanya pemberian lumpur minyak sawit fermentasi yang menyebabkan penurunan konsumsi pakan akibat berkurangnya palatabilitas pakan. Brata (1997) menyatakan bahwa hasil fermentasi dapat meningkatkan palatabilitas ransum sehingga konsumsi ransum dapat meningkat. Meningkatnya konsumsi ransum dipengaruhi oleh rasa enak dari lumpur sawit fermentasi dan hasil fermentasi dapat meningkatkan palatabilitas ransum.

Tingginya rata-rata konsumsi pakan babi bali pemberian 15\% lumpur sawit fermentasi disebabkan oleh tingkat pemberian lumpur sawit fermentasi pada taraf $15 \%$ yang mempengaruhi palatabilitas ternak pada perlakuan $15 \%$ yang lebih tinggi dari pada perlakuan lainnya. Tingginya rata-rata konsumsi pakan babi 
ISSN $1978-3000$

Tabel 6. Rataan konversi pakan babi bali

\begin{tabular}{|c|c|c|c|c|c|}
\hline \multirow{2}{*}{ Perlakuan } & \multicolumn{3}{|c|}{ Konversi pakan } & \multirow{2}{*}{ Jumlah } & \multirow{2}{*}{ Rataan } \\
\hline & 1 & 2 & 3 & & \\
\hline R0 & 7,66 & 7,76 & 7,91 & 23,33 & $7,78^{b}$ \\
\hline $\mathrm{R} 1$ & 6,63 & 8,73 & 6,74 & 22,09 & $7,36^{\mathrm{ab}}$ \\
\hline $\mathrm{R} 2$ & 6,83 & 7,03 & 6,93 & 20,79 & $6,93^{\mathrm{ab}}$ \\
\hline R3 & 6,46 & 5,89 & 5,98 & 18,33 & $6,11^{\mathrm{a}}$ \\
\hline $\mathrm{R} 4$ & 7,34 & 7,36 & 7,55 & 22,25 & $7,42^{\mathrm{ab}}$ \\
\hline
\end{tabular}

Keterangan: R0:Tanpa pemberian Lumpur sawit fermentasi, R1: Lumpur sawit fermentasi 5\%, R2:Lumpur sawit fermentasi 10\%, R3: Lumpur sawit fermentasi 15\%, R4: Lumpur sawit fermentasi $20 \%$. Superskrip yang berbeda pada kolom rataan menunjukkan berbeda nyata $(\mathrm{P}<0,05)$

bali pemberian $15 \%$ lumpur sawit fermentasi juga disebabkan oleh lumpur sawit yang difermentasi dengan kapang Trichoderma harzianum lebih kaya dengan vitamin B1 yang berasal dari sumbangan Trichoderma harzianum sewaktu proses fermentasi, dimana vitamin B1 dapat merangsang nafsu makan pada ternak. Anggorodi (1985) menyatakan bahwa dari semua zat makanan, vitamin B1 mempunyai pengaruh paling banyak terhadap nafsu makan.

Buckle et al., (1987) disitasi Erwin (1997) menyatakan bahwa bahan makanan yang telah difermentasi akan mempunyai daya cerna yang lebih tinggi. Pada taraf pemberian $15 \%$ lumpur minyak sawit fermentasi, babi mampu mensintesa kandungan gizi lumpur sawit. Farrel (1986) menyatakan bahwa batas pemberian lumpur minyak sawit fermentasi pada babi adalah taraf $15 \%$. Pada batas $15 \%$ babi masih mampu mentolerir kandungan pakan lumpur sawit, sesuai dengan pendapat Sinurat et al., (2000) yang mengatakan bahwa pada batas pemberian $15 \%$ lumpur minyak sawit fermentasi tidak menggangu pertumbuhan, konsumsi ransum dan persentasi ransum.

Pemberian 20\% lumpur minyak sawit fermentasi, didapat konsumsi ransum yang lebih sedikit dibanding pemberian $15 \%$ lumpur sawit fermentasi, hal ini diduga disebabkan karena pemberian $20 \%$ lumpur sawit fermentasi tidak dapat ditolerir oleh babi bali. Menurut Sinurat (2000) mengatakan semakin tinggi pemberian lumpur minyak sawit fermentasi akan menyebabkan penurunan performans, konsumsi ransum dan menyebabkan pertumbuhan yang lebih lambat. Selanjutnya Karo-karo et al., (1994) mengatakan bahwa taraf pemberian lumpur sawit fermentasi pada babi yaitu sampai batas $15 \%$.

\section{Konversi Pakan}

Berdasarkan Tabel 6 di atas, didapat rataan konversi pakan babi bali pada perlakuan tanpa pemberian lumpur sawit fermentasi sebesar 7,78, pemberian $5 \%$ lumpur sawit fermentasi sebesar 7,36, pemberian $10 \%$ lumpur sawit fermentasi sebesar, 6,93 pemberian 15\% lumpur sawit fermentasi sebesar 6,11, dan pemberian $20 \%$ lumpur sawit fermentasi sebesar 7,42. Hasil analisis sidik ragam menunjukkan bahwa pemberian lumpur minyak sawit fermentasi yang difermentasi dengan kapang Trichoderma harzianum berpengaruh nyata $(\mathrm{P}<0,05)$ terhadap konversi pakan babi bali. Hal ini menunjukkan bahwa lumpur sawit fermentasi memberikan pengaruh baik terhadap konversi pakan. Brata (1997) melaporkan bahwa konversi ransum dipengaruhi oleh jumlah konsumsi 
Tabel 7. Rataan suhu dan kelembaban kandang setiap minggu pengamatan

\begin{tabular}{ccccccc}
\hline \multirow{2}{*}{ Minggu } & \multicolumn{3}{c}{ Suhu $\left({ }^{\circ} \mathrm{C}\right)$} & \multicolumn{3}{c}{ Kelembaban $(\%)$} \\
\cline { 2 - 6 } & Pagi & Siang & Sore & Pagi & Siang & Sore \\
\hline 1 & 25.42 & 29.14 & 28.85 & 94.71 & 91.00 & 93.57 \\
2 & 25.85 & 29.14 & 27.00 & 93.42 & 91.14 & 94.00 \\
3 & 25.71 & 29.71 & 28.00 & 93.85 & 89.85 & 93.28 \\
4 & 25.28 & 28.14 & 26.71 & 95.14 & 92.85 & 93.42 \\
5 & 25.28 & 28.85 & 27.00 & 95.14 & 92.14 & 94.00 \\
6 & 25.42 & 28.71 & 27.00 & 94.71 & 92.28 & 93.42 \\
7 & 25.85 & 29.28 & 27.28 & 93.42 & 90.85 & 93.85 \\
8 & 25.71 & 29.42 & 27.42 & 93.85 & 90.17 & 94.00 \\
Rata-rata & 25.56 & 29.048 & 27.40 & 94.28 & 91.28 & 93.69 \\
\hline
\end{tabular}

Keterangan :Suhu dan kelembaban diukur pada pukul 7.00 WIB, pukul 12.00 dan pukul 17.00 WIB.

ransum dan tingkat pertambahan berta badan

\section{Keadaan Suhu dan Kelembaban Kandang}

Rata-rata suhu kandang pada pagi hari yaitu $25,56^{\circ} \mathrm{C}$, siang hari $29,04^{\circ} \mathrm{C}$, sore hari $27,40^{\circ} \mathrm{C}$ dan kelembaban kandang pagi hari $94,29 \%$, siang hari $91,28 \%$, dan sore hari $93,69 \%$. Untuk lebih jelas dapat dilihat pada Tabel 7. Rata-rata suhu dan kelembaban kandang tersebut menunjukkan suhu dan kelembaban di atas normal. Sesuai dengan pendapat Williamson dan Payne (1993), mengatakan bahwa suhu kandang babi normal yaitu berkisar antara $21^{\circ} \mathrm{C}-24^{\circ} \mathrm{C}$, dan kelembaban normal kandang babi yaitu $70 \%$. Keadaan suhu dan kelembaban kandang di atas normal akan menyebabkan babi banyak mengeluarkan energi untuk beradaptasi dengan lingkungan, sesuai dengan pendapat Anonimus (1981),yang mengatakan apabila suhu kandang di atas normal maka babi akan melakukan adaptasi terhadap lingkungan yang panas tersebut dan babi akan mengalami kesulitan dalam membebaskan diri dari suhu yang panas disebabkan karena babi tidak memiliki kelenjar keringat untuk mengatasi lingkungan yang terlampau panas.

\section{SIMPULAN}

Pemberian lumpur minyak sawit yang difermentasi dengan kapang Trichoderma harzianum dapat meningkatkan pertambahan bobot badan babi bali. Pertambahan bobot badan yang paling tinggi yaitu pada pemberian 15\% lumpur minyak sawit fermentasi. Pemberian lumpur minyak sawit yang difermentasi dengan kapang Trichoderma harzianum berpengaruh nyata terhadap konversi pakan babi bali. Konversi pakan yang paling rendah yaitu pada pemberian $15 \%$ lumpur sawit fermentasi.

\section{DAFTAR PUSTAKA}

AAK. 2000. Pedoman Lengkap Beternak Babi. Kanisius. Yogyakarta.

Anonimus. 1999. Pedoman Lengkap Ternak Babi. Yayasan Kanisius. Yogyakarta.

2003. Tehnik Beternak babi. Badan penelitian dan Pengembangan Pertanian. Balai Pengkajian Teknologi Pertanian. Gedong Johor, Sumatera Utara.

Anggorodi, R. 1985. Kemajuan Mutakhir Ilmu Makanan Ternak Unggas. Penerbit Universitas Indonesia (UIPress). Jakarta. 
Aritonang, D. 1986. Perkebunan Kelapa Sawit Sumber Pakan Ternak. Jurnal Penelitian dan Pengembangan Pertanian V.01 No. 4: 93-99.

Brata, B. 1997. Seleksi dan penggunaan galur Trichoderma harzianum untuk meningkatkan mutu isi rumen serta pengaruhnya terhadap performans ayam broiler. Tesis. Program Pascasarjana Universitas Andalas. Padang.

Blakely, D dan D. Bade. 1994. Ilmu Peternakan. Edisi ke empat. Gadjah Mada University Press. Yogyakarta.

Darana, S. 1995. Penggunaan sorgum bicolor 1 moench yang difermentasi dengan kapang Rhizopus oligosporus dalam ransum ayam broiler. Disertasi IPB. Bogor.

Devendra, H. 1997. Utilization of Feedingstuffs From the Oil Palm. Malaysia Agriculture research and Development Institute. Serdang selangor, Malaysia.

Erwin, M. 1997. Pengaruh pemberian lumpur minyak sawit yang difermentasi dengan kapang Trichoderma harzianum terhadap performans ayam broiler. Skripsi Fakultas Pertanian Universitas Bengkulu. Bengkulu.

Fardiaz, S. 1992. Mikrobologi Dasar. Gramedia. Jakarta.

Fati, N. 1997. Pengaruh penggunaan dedak padi padi yang difementasi dengan galur Trichoderma terseleksi terhadap performa ayam broiler. Tesis. Program Pascasarjana, Universitas Andalas. Padang.

Hardjosubroto, W. 1994. Aplikasi Pemuliabiakan ternak di Lapangan. Gramedia Widiasarana Indonesia. Jakarta.

Karo-karo, S. 1994. Penelitian Sistem Usaha Tani Ternak Ayam Buras Di Lahan Pekarangan Petani Tanaman Pangan. Laporan Akhir Penelitian. Sub balai penelitian ternak.

Lubis, A. 1995. Pusat Penelitian Kelapa Sawit. Jurnal Penelitian dan
Pengembangan Pertanian. V 03. No I: 11-14.

Medan Pos. 1998. Limbah Pabrik Kelapa Sawit Resahkan Penduduk. Harian Medan Pos, 2 Januari 1998.

Perez, R. 1997. Feeding Pigs in the Tropics. FAO Animal Production and Health. Food and Agriculture Organization of the United Nations. Paper 1342. Rome.

Rabbani, B dan H. Susanto. 1996. Fermentasi, Bioteknologi Alternatif meningkatkan Mutu Pakan Ternak. Poultry Indonesia, No.204: 18-19.

Satyawiharja, B. 1984. Fermentasi Media Padat dan Pemanfaatannya Dep P \& K Republik Indonesia.

Sihombing, D.T.H. 1997. Ilmu Ternak Babi. Gadjah Mada University Press. Yogyakarta.

Sinurat, P. 2000. Pemanfatan lumpur sawit untuk ransum unggas: 1. Lumpur sawit kering dan produk fermentasinya sebagai bahan pakan ayam broiler. JITV. 5 (2): 107-112.

Sinurat, P. 2003. Pemanfaatan Lumpur Minyak Sawit Untuk Bahan Pakan Unggas. Jurnal Penelitian Wartazoa vol 13 no 2. Bogor.

Smith, J. and M, Soesanto. 1998. Pemeliharaan, Pembiakan dan Penggunaan Hewan Percobaan di Daerah Tropis. DGHE IDP Of Australian Universities and Colleges. UI-Press. Indonesia.

Stanbury, P.F. and A, Whitaker. 1984. Principles of fermentation Technology. Pergamon Press.

Sutopo, T. 1987. Pemanfaatan Jerami Padi pada Fermentasi Trichoderma viride 04, L66 Untuk Menghasilkan Sellulase. Fakultas Teknologi Pertanian IPB. Bogor.

Wiliamson, G and W, Payne. 1993. An Introduction to Animal Husbandry In The Tropic, $2^{\text {nd }}$ Edition. Longmans Green and co ltd. 